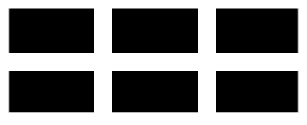

ThE WILliAM DAVIDSON INSTITUTE AT THE UNIVERSITY OF MICHIGAN BUSINESS SCHOOL

\title{
The Political Economy of Industrial Policy in China: The Case of Aircraft Manufacturing
}

\author{
By: Andrea Goldstein
}

William Davidson Institute Working Paper Number 779

July 2005 


\title{
THE POLITICAL ECONOMY OF INDUSTRIAL POLICY IN CHINA: THE CASE OF AIRCRAFT MANUFACTURING
}

\author{
Andrea Goldstein \\ OECD Development Centre \\ 12 Boulevard des lles \\ 92130 Issy-les-Moulineaux \\ FRANCE \\ Andrea.goldstein@oecd.org
}

Key words: aerospace, China

JEL classifications: H11, L62, O14

I thank Manuel Albaladejo, Peder Andersen, John Frankenstein, Guoyong Liang, Dave Pritchard, and Harm-Jan Steenhuis, as well as participants at the $16^{\text {th }}$ Annual CEAUK (Chinese Economic Association UK) Conference in London (21-22 March 2005) and the joint CEAUK-ACESA (Association for Chinese Economic Studies Australia) Conference at Chongqing University (31 March-1 April 2005), for most useful comments and suggestions on earlier drafts. The opinions expressed in this paper do not reflect the position of the OECD, the OECD Development Centre, or their member states. 


Abstract
Since 1960, only one new country, Brazil, has succeeded in delivering more than one
civil jet per month. Otherwise, all the countries now offering world-class planes were
established in aviation by the end of World War I. This being said, low-cost producers
within several of the newly emerging markets have already acquired front-end
manufacturing expertise as a direct result of industrial offset contracts and/or other
forms of technology transfer. In all such cases, government intervention, notably
through state ownership, has been predominant, but failures have been numerous in
view of the difficulty of aligning ownership structure to financial, managerial, and
technological requirements and of garnering the support of domestic interest groups.
In this paper the focus is China's efforts to build a world-class aircraft manufacturing
industry. In the first half of the 1990s the potential of the Chinese industry to mount a
competitive challenge to Western aircraft builders was largely discounted. Nowadays,
as China strives to bear the ARJ-21 project to execution and even considers entering
the market for wide-bodies, the threat is taken more seriously. The growth in the
Chinese air transport market has reinforced the bargaining power of national aircraft
producers and authorities are giving priority to building science and technology capacity
in this area. Progress in creating military/civilian synergies has proven much more
modest - especially when compared to the shipbuilding industry - and better
coordination in the overall industry comes a distant fourth in the explanations' peaking
order.

\section{Table of contents}

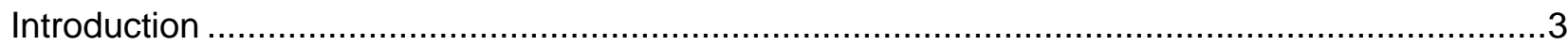

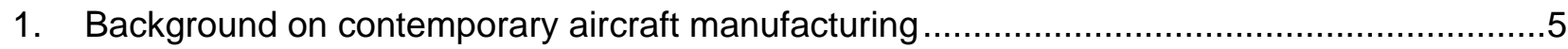

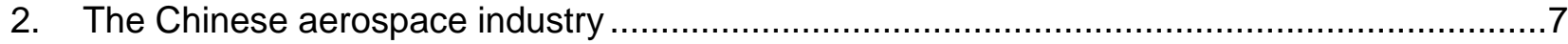

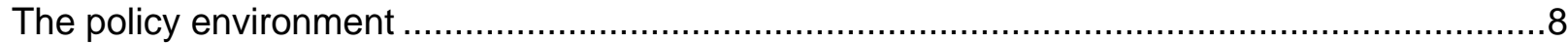

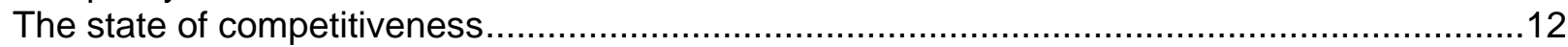

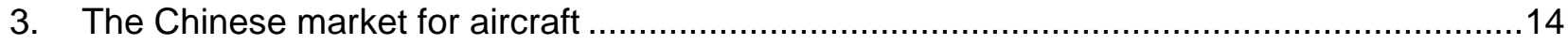

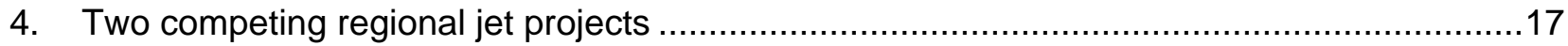

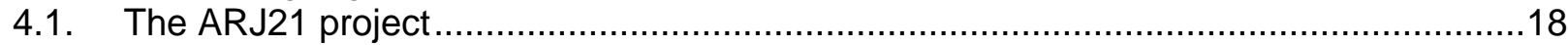

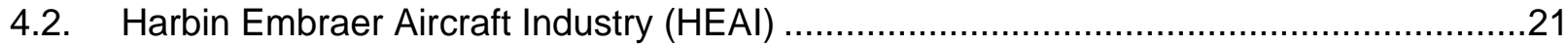

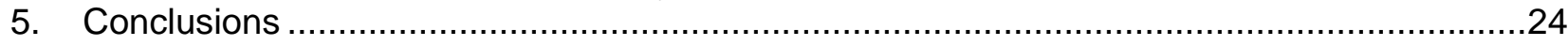

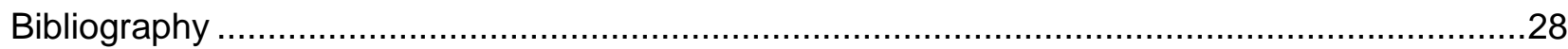

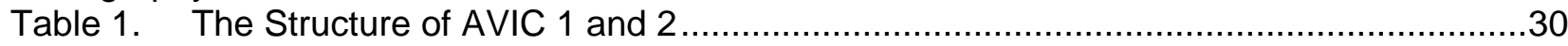

Table 2. Main Airbus and Boeing Subcontracting Work in China .......................................31

Table 3. Trade in Aircraft, Spacecraft, and Parts Thereof ................................................. 


\section{Introduction}

Over the past decade or so, China has emerged as one of the main - if not the main location for low-end, labor intensive manufacturing in many global production networks. As the country's income and salary levels increase, especially in coastal zone and selected inland locations, one of the crucial questions facing policy-makers, scholars, managers and competitors is whether the same successful experience can be replicated climbing up the value chain (Nolan 2005)..

While many remain skeptic, ${ }^{1}$ some early indicators suggest that this is possible, in particular in transport equipment production. Shipyards which less than ten years ago were still turning out simple container vessels and bulk carriers and had a world market share below 1 per cent now produce 13 per cent of the world's new ships, behind only South Korea and Japan. In 2004, China had a backlog of some 800 ships on order, including for sophisticated liquefied natural-gas carriers to mostly foreign specifications. ${ }^{2}$ Although labor productivity in the Chinese shipyards lags far behind that in South Korean and Japanese yards, which are about even, China, like Japan, is taking steps to channel much of its trade into Chinese-made ships. ${ }^{3}$ As per the car industry, "many feel that it is only a matter of time before vehicles assembled in China make significant inroads in the Japanese market" (Sturgeon and Florida 2004, p. 64), although growth is likely to be "rapid, but uneven and painful" (Doner et al. 2004, p. 175). ${ }^{4}$

\footnotetext{
${ }^{1}$ Possibly no coincidence is more telling that the fact that on the same date (8 December 2004) Lenovo acquired IBM's venerable PC business and Chen Jiulin, the once high-flying chief executive of China Aviation Oil (Singapore), was arrested in connection with a \$550 million derivatives trading scandal.

${ }^{2}$ In December 2003 Shanghai Waigaoqiao Shipbuilding Co. scored an order for two bulk carriers from NYK line, the first major purchase by a Japanese owner, who traditionally have favored domestic producers. Jinling Shipyard has built Ville de Bordeaux, the giant cargo ship that transports the different components for the A380 between Hamburg, Chester, Cadiz, and Saint-Nazaire. Korea's Hyundai Heavy Industries, the world's largest shipbuilding company, has three joint ventures in China, and it already farms out some of its low-technology shipbuilding work to these companies. See "On the crest of a wave", China Economic Review, June 2004 and "Korean Shipbuilders See China’s Shadow”, The New York Times, 6 January 2005.

${ }^{3}$ Hudong-Zhongua Shipbuilding, which is state-owned, wants to become the main supplier of liquefied gas tankers to feed the nine L.N.G. terminals that China plans for 2010.

${ }^{4}$ Heilongjiang's Qiqihar Locomotive has also begun selling freight trains to Australia. See "By Plane, Train... Or Helicopter”, China Today, October 2004.
} 
In this paper the focus is on aircraft manufacturing. In this industry, success depends on design and manufacturing strength, ${ }^{5}$ the price and operational costs of the aircraft, and after-sale services provided to customers, that are relatively reduced in number but are spread around the world. Launch and research and development (R\&D) costs, as well as survival risk, are high, while cost reductions over time from learning by doing are unusually large. Assembly and system integration are increasingly seen as key competencies for successful primes, as supply chain management and associated risks are pushed down on Tier I and II suppliers. Finally, the weight of history goes heavily against wholly new aircraft market entrants, in all segments. Since 1960, only one such company, Brazil's Embraer, has succeeded in delivering more than one civil jet per month (Goldstein 2002a). ${ }^{6}$ Otherwise, all the countries now offering world-class planes were established in aviation by the end of World War I.

In China, the 863 Program (which included aerospace among the areas that authorities targeted to expand and advance the high-technology base) produced rather meager results, as did some ambitious joint ventures launched in the 1990s. Moreover, the rationalization of the state-owned aerospace industry is still pending. Nonetheless, government considers this a strategic industry, although not an official "pillar" one (Bureau of Export Administration 1999), and sees Chinese companies becoming worldclass producers by 2012 , in part via close cooperation with major international aerospace firms and enhanced supplier relationships with non-Chinese primes. China is trying to leverage the interest that foreign manufacturers have in accessing the domestic market to negotiate favorable terms for partnerships of various kinds.

Regional jets, with 50 to 110 seats and a maximum flight range between 900 and 1,700 nautical miles, are seen by the Chinese as the most appropriate entry points into worldclass aircraft production, also in view of the likely explosion in the demand for this class

\footnotetext{
${ }^{5}$ The actual manufacture of an aircraft consists of three principal stages: fabrication of primary parts (metal sheets and plates, parts produced using computerized and non-computerized machines, and prefabricated parts), assembly of major component, and final installation of the aircraft's various operating systems (such as wiring and electronics) into the structure.

${ }^{6}$ While Airbus and Bombardier did not exist in their current form in the 1960s, the companies that now comprise them did.
} 
of planes once the liberalization of civil aviation is completed and carriers are free to adopt the hub-and-spokes network structure. The two key, separate projects in this respect are those that involve, respectively, the national champion and Embraer, associated with a Tier 2 local assembler. In the latter case, this ambitious project is part of a broader strategy aimed at turning China's Northeast from "largest rust belt to fourth economic engine" (Li 2004).

This paper provides some evidence and preliminary analysis on a set of interrelated questions. Which motivations underlie industrial reform and policies in China's aircraft industry? What role do the conversion of the military-industrial complex, privatization and foreign investment play in this strategy? Why were two competing projects launched? Why did the Chinese authorities decide to partner with Embraer, a relatively new kid in the field of global aerospace, and not with other manufacturers with a more established track record? And how real is the risk that the Chinese may be opportunistic in their acting, to protect the interests of its national champions and maximize their chances of becoming a serious global contender to Embraer?

The paper is organized as follows. In the next Section the main features of contemporary aircraft manufacturing are presented. Section 2 sketches the recent history of the Chinese industry. Section 3 turns the attention to the Chinese market for aircraft, regional jets in particular. Sections 4 and 5 present the experience of the two competing projects to, respectively, develop a brand-new Chinese regional jet and assemble a Brazilian one. On the basis of this comparison, Section 6 concludes by linking the themes of corporate capabilities and industrial policy.

\section{Background on contemporary aircraft manufacturing}

Aircraft are complex products made of a great variety of sub-components. According to Piore (2004, p. 4),

"the industry has never been able to achieve the kind of standardization common in automobile production (or in pin factories). The production line in airplane 
assembly is characterized by workmen hammering and stretching the components to get them to fit together. All along the line are boxes of small metal plates known as "shimmies" which are inserted in an ad hoc way to fill spaces left at the joining of parts that are not fully compatible".

As investment needs are huge, uncertainty high, lead times long, and economies of scale and learning in production important, a small number of players dominate the industry. Notwithstanding low standardization, the degree of vertical integration has decreased dramatically over the past 20 to 30 years on account of increased technological obsolescence, higher investment needs, and greater financial market discipline. In a context where the range of possible trajectories, and therefore technological differentiation, is severely constrained (Sutton 1998), aircraft manufacturing is moving towards increasing modularization, consolidation, and global outsourcing patterns. Assemblers remain responsible for the design and final assembly of the aircraft's major sections (such as barrel, wings, and engines) into the structure, but fabrication of primary parts (metal sheets and plates, parts produced using computerized and non-computerized machines, and prefabricated parts) and assembly of major components are outsourced to major Tier I partners. This in turn has resulted in the consolidation of the industry for major specialized products (engines, avionics, landing gears, power units) that rely in turn on a myriad of sub-contractors.

A study of the US large civil aircraft industry identified the following as the major competitiveness factors (ITC 2001, quoted in Hartley and Braddon 2002):

- Low labor costs and the ability to adjust the size of the workforce to increasing capital/labor intensity;

- The availability of government support to subsidize production costs and allow firms to offer lower prices for their aircraft (e.g. low interest loans; launch aid);

- The ability of top tier suppliers to manage their supply chains and improve the efficiency of their supply network. 
In order to remain competitive, suppliers and subcontractors need to acquire both intangible resources (managerial skills, reputation, ability to master product and component design, component sourcing, inventory management, testing, packaging, and outbound logistics) and "hard" manufacturing technologies such as computerized numerical control tools (CNC) or automated handling. Co-location is not crucial -

production runs are short, inventory management does not require strict adherence to just-in-time imperatives, and information and communications technologies allow sharing information and managing the supply chain. Nonetheless, for individual companies, networks of firms, and institutions, the learning cycle for acquiring such critical capabilities is rather long, which explains the high degree of persistence of major aerospace clusters such as Seattle, Toulouse, Bristol, and Montreal.

Although there are differences across countries, governments have always played a major role as customers (especially for military aircraft), regulators, and investors. In non-OECD countries, in particular, state ownership, has been predominant and some producers have acquired front-end manufacturing expertise as a direct result of industrial offset contracts and/or other forms of technology transfer (Goldstein 2002b). With the exception of Brazil, however, most new comers have failed to gain sufficient competitiveness in view of the difficulty of aligning ownership structure to financial, managerial, and technological requirements and of garnering the support of domestic interest groups.

\section{The Chinese aerospace industry}

In the 1980s, China made a determined effort at building an indigenous aerospace capability (Nolan and Zhang 2002, 2003). Based on reverse engineering of the Boeing 707, the Ministry of Aerospace Industries built a large civilian airliner, the Y-10, while Xi'an Aircraft Corporation (XAC) developed its own 60-seat turbo-prop regional aircraft, the $\mathrm{Y}-7$. Both proved to be major commercial failures and safety concerns further 
compounded matters. ${ }^{7}$ Manufacturing of military aircraft proved more auspicious, to the point that a relatively advanced jet trainer, the K-8 Karakorum, was jointly developed with Pakistan.

\section{The policy environment}

A resolution passed by the $8^{\text {th }}$ National People's Congress put the entire aviation industry under AVIC (Aviation Industries of China) control in 1993, with the aim of creating an ultra-large industrial group, combining military and civil aviation and capable of competing globally. AVIC core aerospace business, however, remained small and too widely diversified across unrelated production enterprises, while its staff was overblown. To counter this situation, the Ministry of Aviation devised a 'three-step take-off plan'. AVIC started by signing purely off-set contracts with Boeing (manufacture of vertical fins, horizontal stabilizers and rear fuselage) and McDonnell Douglas (the nose section and horizontal stabilizers for the MD-82 and MD-90).

In the latter case, between 1985 and 1994 Shanghai Aviation Industrial Corporation (SAIC), a joint venture with the China National Aero-Technology Import and Export Corporation (CATIC, the principal purchasing arm of China's military), assembled 35 MD-82 and MD-83 jetliners. To ensure that all of these aircraft would receive U.S. Federal Aviation Administration certification, ${ }^{8} \mathrm{McDonnell}$ Douglas completely renovated SAIC's factories and provided huge amounts of technical data, as well as 55,000 manhours of technical training. ${ }^{9}$ The cooperation with McDonnell Douglas - the only Western firm which was willing to transfer real competencies to the Chinese as a way to capture market share and sort itself out of the crisis that eventually cost it to be taken over by Boeing - was extended. The Trunkliner program aimed at producing the MD-90 at the SAIC facility, with three AVIC subsidiaries (Xi'an, Shenyang, and Chengdu)

\footnotetext{
${ }^{7}$ In 2000, a Y-7 exploded in mid-air. Following the conclusion of the crash investigation, all Y-7s were taken out of service in June 2001.

${ }^{8}$ Most of these were sold to customers in China, but five were sold to TWA.

${ }^{9}$ SAIC bought US-made machine tools. Six dual-use machine tools were diverted to the Nanchang Aircraft Company (which makes cruise missiles as well as some civilian items), although key conditions in the licenses required the equipment to be used for the Trunkliner program only (US House of Representatives 1999).
} 
expected to fabricate and assemble about 75 per cent of the aircraft (essentially everything except the engines and avionics). The resistance of the Civil Aviation Administration to buy a large quantity of MD-90s and other problems meant that the number of aircraft covered by the agreement fell from 1992 (when initial discussion was held) to three by July 1998 (Nolan 2001, p. 68). In the end only two exited the factory floor, with local content in the 50-to-60 per cent range.

In the second phase, co-operation with Airbus and Singapore Technologies Group was expected to lead to jointly design and manufacture of the Air Express 100, a 100seater. ${ }^{10}$ Partners however grew increasingly concerned with China's insistence on being responsible for systems integration, despite the clear lack of capabilities in this area (USCC 2005, p. 82). The final phase involved designing and manufacturing of $180-$ seater aircraft by 2010. None of these objectives advanced and, with the industry reeling and its development strategy in tatters, in early 1999 the Chinese government decided to split AVIC into two fully integrated parts, AVIC I and AVIC II. ${ }^{11}$

Each group contains the full range of production and sales of military and civilian aircraft, airborne equipment as well as non-aeronautical products (Table 1). ${ }^{12}$ The stated goal of the reform was to break up the monopoly and foster fair competition, while also maintaining mechanisms for non-market co-operation. The decision, however, went against trends in the world's aerospace industry towards consolidation (Nolan and Zhang 2002, 2003). ${ }^{13}$ Alternatives existed - such as separating the aerospace from the non-aerospace business, or the civilian from the military business, or engines and avionics from the airframe business - but they were disregarded. On the

\footnotetext{
${ }^{10}$ According to Zhu Yuli, in charge of AVIC until he resigned in 1998, "We cannot accept that we will not have an internationally competitive industry. We were determined to develop a 100-seater aircraft, and failed; as general manager of AVIC, I took this as my lifetime regret. But it is still both possible and necessary to continue" (see "The China Syndrome”, Financial Times, 8 January 2000).

${ }^{11}$ The other main branches of the national defence industries under COSTIND were also split into two. These include the China National Nuclear Industries General Company, the China National Aerospace Industries General Company, the China National Shipbuilding General Company, and the China National Armaments General Company.

${ }^{12}$ For example, AVIC is the largest manufacturer of small cars in China.

${ }^{13}$ Not only in the North Atlantic, but also in Asia - Korea Aerospace Industries was formed in 1999 through the merger of the aerospace divisions of Daewoo, Hyundai and Samsung.
} 
contrary, stovepiping - the practice of taking a piece of intelligence or a request that should be pushed through the chain of command and bringing it straight to the highest authority - is rife, curtailing efforts to encourage open communication and effective coordination (Bitzinger 2000) ${ }^{14}$ Workforce reduction has also been very modest according to Bitzinger (2005), "AVIC has downsized by only 10 per cent overall, and this was likely accomplished through attrition, that is, retirement and job-leavers". In terms of providing clear strategic guidelines, frictions between the Commission of Science, Technology, and Industry for National Defence (COSTIND) and the State Asset Supervision and Administration Commission (SASAC) are reputedly rife. ${ }^{15}$

Nonetheless, some rationalization has taken place. Efforts have been made to streamline operational procedures, improve accounting and financial standards, and recruiting younger managers. ${ }^{16}$ In May 2003 AVIC II spun off some of its non-defense activities, including mini-car and helicopter production, to create AviChina Industry \& Technology Co Ltd (AviChina). ${ }^{17}$ Shares of the company have been listed on the main board of the Stock Exchange of Hong Kong in October 2003, raising HK\$1.936 billion (US\$248.2 million) from the initial public offering. European Aeronautic Defence and Space Company (EADS) has become the second largest shareholder of AviChina by holding a 5 per cent stake.

It is also important to note in passim three additional policy developments that affected the industry's fortunes, jointly with aviation liberalization (see below). First, as part of its transformation from a land-based power to a smaller, mobile, high-tech military capable of mounting defensive operations beyond its coastal borders, the military has grown its power-projection capability over recent years. In 1995-2002, in particular, China has acquired the license to produce up to $352 \mathrm{SU}-27$ and SU-30 fighter ground attack (FGA)

\footnotetext{
${ }^{14}$ On the inconsistencies of Chinese industrial policy, and in particular of the zhua da fang xiao ("grasping the large and releasing the small”) approach, see Steinfeld (2004).

${ }^{15}$ Anonymous interview at the Development Research Centre of the State Council, Beijing, 28 March 2005. The National Development and Reform Commission (NDRC) is a third key institution involved in the aircraft industry.

${ }^{16}$ Interview with Ken Yata, Vice President China Business Development, Boeing, Beijing, 30 March 2005.

${ }^{17}$ Details of the reorganization are available in the global offering's prospectus at http://www.hkex.com.hk/listedco/listconews/sehk/20031021/LTN20031021012.htm.
} 
aircraft from Russia (SIPRI 2004) ${ }^{18}$ Moreover, work has also been performed to pursue unmanned aircraft technologies both domestically and from foreign partners. ${ }^{19}$ China is indeed marketing its drones to friendly nations in Asia and Africa. However, the mainstay of the air force continues to be the 1960s-vintage F-7, Russian staff remains on-site to oversee SU-27 production and ensure quality control, and few opportunities seem to have emerged so far for civil-military integration through sharing of personnel, production processes, and materials (Bitzinger 2000, 2004).

Second, when China negotiated WTO accession, other members asked her to make commitments under the Government Procurement Agreement and the Agreement on Trade in Civil Aircraft, which seeks to provide a comprehensive basis for free and fair trade in the aircraft sector. ${ }^{20}$ China has not offered to join this agreement. Nevertheless, China made commitments in the November 1999 agreement with the United States reducing tariffs and eliminating quotas on related products. ${ }^{21}$

Finally, ever since aerospace and aircraft manufacturing have started receiving priority status in the context of China's science and technology program, research, training and education resources to reinforce design and support capabilities have increased. Two major wind tunnel facilities for aerostructures testing were completed in the late 1990s in Beijing and Xi'an (USITC 2001, Table 7-12). In the $10^{\text {th }}$ Five Year Plan, more than CHY5 billion will be spent on research and development in commercial aerospace technology, as compared to CHY1.7 billion in the $9^{\text {th }}$ Plan. ${ }^{22}$ China-based scholars do

\footnotetext{
${ }^{18}$ Roughly two decades in the making, the developmental J-10 (F-10) fighter is reportedly based on technology derived from Israel's cancelled Lavi program.

19 “China Is Pursuing Unmanned Tactical Aircraft”, National Defense Magazine, May 2004.

${ }^{20}$ Currently, 12 WTO members, including the 15 members of the European Union, have undertaken obligations under the Agreement on Government Procurement and 25 under the Agreement on Trade in Civil Aircraft. The latter includes tariff-cutting provisions, pricing guidelines, and disciplines on the use of technology transfer requirements and other offsets on foreign aircraft suppliers and on using subsidies to support domestic producers.

${ }^{21}$ Unfortunately, aerospace was not selected for the recent GAO exercise on US companies' views on China's implementation of its WTO commitments (GAO 2004).

22 "Development of China's Aerospace Industry during the $10^{\text {th }}$ Five Year Plan”, Beijing Jiefangjun Bao, 3 December 2001, at http://www.fas.org/spp/guide/china/bjb031201.html.
} 
now account for a very substantial share of paper submissions to the leading journals in the aerospace field. ${ }^{23}$

\section{The state of competitiveness}

Many of the aviation platforms China is now building and deploying still utilize foreign imports for the most crucial subsystems such as propulsion, avionics and fire-control (Medeiros 2004). In addition, China still can not produce a turbo-fan engine or advanced fire-control systems for its newest fighters. The only area where AVIC has recorded some success is in international sub-contracts and sub-system joint ventures (Table 2). In this case, cheap labor and big sales prospects outweigh the troubles. ${ }^{24}$ AVIC firms have progressively evolved into being the sole suppliers of some items (B-747 wing rear ribs, B-737 maintenance doors, BAe 146 doors, Dash-8 cargo doors and LM2500 turbine disks). This is indeed a major advance, when one considers that a decade ago "producers generally procure[d] from an alternate second source when placing aerostructures work in China" (USITC 2001, p. 6-3). Boeing has sourced parts worth US $\$ 500$ million from China between 1980 and 2004, forecast to hit US\$1.3 billion by 2010. For its part, Airbus signed an agreement which targets an annual volume of Chinese purchases of US\$120 million by 2010. In 2002, Airbus China President Guy McCleod said China should be capable of producing entire wings for Airbus within seven years. ${ }^{25}$ In January 2005 Airbus committed to give China a 5 per cent risk-sharing partnership stake for the A350 project and announced the opening of a centre in Beijing to train Chinese staff. ${ }^{26}$ Both Rolls-Royce and Pratt \& Whitney have also been involved in the manufacturing of components in partnership with Xi'an Aero-Engine. ${ }^{27}$ These fast-

\footnotetext{
${ }^{23}$ In 2004, 39 per cent of Aerospace Engineering authors were from China - although the statistics is remarkably lower in the case of the Journal of Aerospace Engineering. Email correspondence with journal editors Firdaus E. Udwadia (also, Professor of Aerospace and Mechanical Engineering, University of Southern California) and Vicky Williams, January 2005. So far, it has proven impossible to find the number of aerospace engineering graduates.

24 “Outsourcing aircraft parts to China, airliners later”, Asia Times, 3 September 2004.

25 “Hidden Currents at China’s Air Show”, Business Week, 13 November 2002.

26 “La Chine sera un partenaire de l’A350”, Le Monde, 14 January 2005.

${ }^{27}$ The Xi'an facility began producing Rolls-Royce’s advanced turbine blades in 1998, with plans calling for it to be responsible for complete engine modules by 2000. As part of the arrangement, Chinese engineers have been working on secondment at BMW Rolls-Royce's Dahlewitz factory in Germany (Cliff 2001).
} 
growing sourcing strategies are mostly about currying favor with Beijing, which authorizes airliner purchases. ${ }^{28}$

The helicopter industry, centered on Harbin Aircraft Industry Group (HAIG) and Jiangxi Changhe Aircraft Industry Co. (JCAIC), has also developed through cooperation with European and US helicopter makers. In 2000 regulations were loosened to allow local private firms and foreign companies to cooperate in designing and making civil helicopters. HAIG has produced the Z9 (the Chinese version of Eurocopter's AS 365N Dauphin twin) for decades and will soon be producing Eurocopter EC 120 Colibri fiveseat helicopters. ${ }^{29}$ The HAIG story is indeed one of the most successful defense conversion (军转民, jun zhuan min) experiences in China, made possible by good leadership, dedication to "retooling" the workforce, emphasis on market research to identify business opportunities, quality control, and flexible organization (Frankenstein 1999, pp. 215-6). Chinese commercial helicopters currently being constructed with Western parts and expertise are expected to take to the skies between 2005 and 2007. In November 2004, JCAIC also signed a joint venture agreement with Agusta for sale, production, marketing and local support of the A109 Power helicopter.

China's MRO industry, which has seen significant foreign investment, ${ }^{30}$ has also grown fast and is winning ever-larger shares of business on cost, quality and turn-around times. Still, sub-contracts remain a marginal source of revenue and, to the extent that it

\footnotetext{
${ }^{28}$ In 2004 the US-China Aviation Cooperation Program (ACP) has launched the Wright Brothers Partnership, a major initiative to train Chinese aviation professionals in the development and operation of safe airlines, aviation infrastructure, and aerospace industries. See "A Sonic Leap Forward”, China Brief, September 2004. In January 2005 Boeing signed deals worth up to US\$7.2 billion to sell 60 of its 7E7 passenger jets to six Chinese airlines.

${ }^{29}$ HAIG, which has a 24-per cent stake in the program, is responsible for the design and manufacture of fully equipped fuselages, complete with their fuel systems. Singapore Technologies Aerospace, with its 15-per cent share, is responsible for access doors, the tail boom and the composite structure of the fenestron tail rotor. With its 61-per cent stake, Eurocopter has engineering leadership, with responsibility for overall design, specifications, ground tests, flight testing, design and production of the drive trains, the avionics suite, electrical systems, overall integration, primary assembly and certification.

${ }^{30}$ For instance Air France Industries, the world's second largest global multi-product MRO provider, has taken 51 per cent of the holding company that controls Hangxin Avionics, one of China's leading independent newgeneration avionics and repair specialists. See "Air France MRO unit refurbing VIP A310s", Aviation News International, 10-12 September 2002. Most recently, China Eastern Airlines and Singapore Technologies Aerospace established a US\$98 million joint venture aircraft repair facility in Shanghai, called Shanghai Technologies Aerospace Company.
} 
does not participate in the decisions over aircraft purchase in China, AVIC's has a limited ability to place leverage on the global aircraft makers. Moreover, the main autonomous entities compete with each other for funds, investment, and subcontracting opportunities and they are unable to co-finance on a large scale.

Perhaps the greatest success story in Chinese aerospace is the launch market. ${ }^{31}$ The government has invested heavily in the development of the Long March family of expendable launch vehicles. Since the CNSA managed to launch the Shenzhou 1 unmanned test capsule in November 1999, China posted 16 Long March launches until 2003. ${ }^{32}$ The milestone for China, however, occurred on 15 October 2003, when CNSA successfully launched its first manned space capsule, the Shenzhou 5. That mission has clearly jump-started China's national space program, giving the government's plans for expanded space activities credibility that they did not previously have.

In aerospace, China's trade balance remains heavily in the red (Table 3). With US\$3,429 million in sales, air, and spacecraft (HTS \#88) was the fourth largest US export to China in 2003. In the case of the EU-25, aerospace only trails cars among major export items.

\section{The Chinese market for aircraft}

The lure of China is as appealing for aircraft manufacturers as for any other global industry. During the period from 1980 to 1997 air travel increased at a rate of 19.7 per cent annually, which is 3.6 times of the world average. ${ }^{33}$ The Civil Aviation Administration of China (CAAC) expects travel demand to grow an average 10 per cent annually through the end of the decade and China's air transport market to trail only the US market by 2020. The 2008 Olympic Games in Beijing and the World Exposition in

\footnotetext{
31 “Tracking government launch trends”, Aerospace America, March 2004.

${ }^{32}$ The only non-government launch, the Ziyuan 4 imaging satellite, is part of a commercial joint venture between the governments of Brazil and China.

33 “Region of Opportunity”, Aviation Week \& Space Technology, 22 February 2004.
} 
Shanghai will be a major chance for China to present itself to the world. Part of that growth is predicated on the continued drive to open new airports. ${ }^{34}$

China's regional airlines are still in their infancy, but the central government's commitment to the Great Western Development Strategy (GWDS) - an effort to improve the living standards of the 367 million Chinese who live far from prosperous coastal China - and the current reform and consolidation in the airline industry will lay a solid foundation for network rationalization (Findlay and Goldstein 2004) ${ }^{35}$ Recent reforms brought an end to revenue sharing by airlines based on seats they provided on each route. In April 2004 a new regulation liberalized prices on short, local routes; on other routes, prices may now float 25 per cent above or 45 per cent below the 9 cents per passenger-kilometer government-set base price.

It must be underlined, however, that many problems remain. The load factor is roughly 10 per cent lower than in the rest of Asia (62-63 vs. 72-73). ${ }^{36}$ Aircraft fly around five to six hours a day and night flights are non-existent, despite many domestic routes taking up to six hours. Given the large capital immobilized in an aircraft, nine to 10 hours are estimated to be necessary for positive returns on investment. Moreover, half of airports are underused, as airlines do not have the correct aircraft type to operate many of the routes. Half of the country's airports (72 out of 143) handle fewer than 200 passengers a day, resulting in heavy losses for the airport operators. Moreover, on 466 of China's 795 air routes the number of daily passengers is lower than 120 . Finally, minnow airlines will

\footnotetext{
${ }^{34}$ The country expects to add another 64 by 2015 for a total of 210. In the 1990s it renovated Beijing's Capital Airport, but that was only a first step. A second phase is to open in 2007, and by 2015 the airport is to be able to handle 60 million passengers and 500,000 aircraft movements annually. In addition, Shanghai has the new Pudong International Airport and Guangzhou, China's busiest southern business center, opened the new Baiyun International Airport in June 2004. Around 36 new airports will be built within the next five years that are suitable for smaller planes.

${ }^{35}$ Inland provinces cover 56 per cent of the China's land area and hold 23 per cent of its population but their per capita GDP is only 60 per cent of the national average. In an effort to close this economic gap, the central government launched the GWDS in January 2000. A secondary goal of this strategy is to better develop the minority areas, which will tie them closer to the rest of China.

36 “The sky’s the limit, if China's airlines reform”, Asia Times, 4 September 2004.
} 
not get a fair chance to grow if legislation does not outlaw seat dumping, cross-route subsidization, and other anti-competitive practices. ${ }^{37}$

At end-2003, 446 of China's 686 jetliners were Boeing aircraft (not counting Hong Kong and Macau), putting the manufacturer's unit market share at 65 per cent and seat share at 70 per cent. Its dominance is based largely in the single-aisle segment that predominates in China. ${ }^{38}$ Airbus, counting only aircraft seating 100 or more passengers, sees a sales potential of 1,600 airplanes in China over the next 20 years. Boeing's forecast, which includes the smaller regionals, is for 2,400. China's major carriers China Southern, China Eastern and Air China - are expected to resort to the 7E7 for national and regional use and to the 777-300ER as a replacement for older $747 \mathrm{~s}$ on European and U.S. flights. Airbus, for its part, expects the high-density BeijingShanghai, Beijing-Guangzhou, Beijing-Hong Kong, and other major inter-city routes to generate demand for $45-50$ A380s. ${ }^{39}$

Short-haul airlines now have a fleet of about 70, accounting for less than 12 per cent of the total. The proportion is still small compared with 35 per cent on average in the world aviation market. Embraer forecast that China alone could buy 635 regional jets in 200423 , out of a global market for 30 to 60-passenger jets over the next 20 years that would total about 3,500 aircraft, meaning a market worth of almost US $\$ 16$ billion. ${ }^{40}$ As a term of comparison, current annual Embraer sales to the United States are worth about US $\$ 800$ million. By 2020 , China's passenger fleet will have 1,852 aircraft and the ratio of regional jets to the total fleet will rise from the current 14.7 per cent to 31.5 per cent. Finally, regional demand for executive jets in the Far East and Pacific trails the North American and European markets, but it has strong potential.

\footnotetext{
${ }^{37}$ Okay Airlines, China's first private, low-cost airline, started operations out of Tianjin in March 2005, using a Boeing 737-900 on lease from Korea.

${ }^{38}$ See http://www.boeing.com/companyoffices/aboutus/boechina.html.

${ }^{39}$ In January 2005 Airbus and China Southern signed a US\$1.4 billion deal for five A380s.

40 “China enters regional jet market”, CNN, 1 October 2002.
} 


\section{Two competing regional jet projects}

In the Asian aviation industry, Korea and Indonesia looked at the regional jet sector in the 1990s, but for different reasons they could not build up the required capabilities (Goldstein 2002a). Then, in September 2000, Japan's Mitsubishi Heavy Industries was reported to be planning to develop a 30-passenger jet for the U.S. and Japanese markets at a cost of about US $\$ 400$ million. With a prototype ready by 2007 , this would be Japan's first passenger jet and the first passenger aircraft developed there since the 64-seat YS-11 in the 1960s. ${ }^{41}$ JADC (Japan Aircraft Development) has also proposed an 80/110-seat RJ family. Known as YS-X, this effort is effectively a reincarnation of the YS-X proposal that was active in the mid-1990s and canceled in 1997. This YS-X, in turn, was distantly related to the joint Boeing/JADC $7 \mathrm{~J} 7$ proposal in the 1980 s. Finally, Russia has tried for years to rationalize its fragmented and imploding civil aviation sector, with a government-funded RRJ (Russian Regional Jet) as a new foundation. Long-time fighter manufacturer Sukhoi has been tentatively tapped to lead this effort, which caps a decade of unsuccessful attempts to create a Yakovlev or Tupolev RJ product.

Chinese authorities initially identified Fairchild Dornier as the regional jet manufacturer most amenable to enter into negotiations to trade technology sharing and transfer with privileged market access. In the late 1990s, as the smallest of the three remaining firms in this sub-sector, Fairchild was desperate to make inroads in the global market dominated by Bombardier and Embraer. Hainan Airlines was operating 19 328JETs and wanted to expand its fleet to a potential 40. However, government approval for the deal was delayed and even a November 2001 visit by Germany's Chancellor Gerhard Schroeder to China could not accelerate the process. ${ }^{42}$ The Chinese wanted to push through demands of increased technology transfer - such as the production of airframe subassemblies and the joint development of a scaled down 50-65-seat version of the

\footnotetext{
${ }^{41}$ Mitsubishi Heavy cooperated with five other Japanese manufacturers to build the YS-11. During the late 1990s, it was also involved in the YS-X project, which explored the possibility of Japan building a 100-seat regional jet.

42 “New Funding Agreement To Bolster Fairchild Dornier”, Aviation Week, 28 January 2002.
} 
728. Even if the company said that to outsource production work would make sense not just because of market access, but because of cost savings and engineering capabilities, the Chinese still refused to clear the deal.

In 2003 China's D'Long Group announced it would buy the 728 development program from Fairchild Dornier's bankruptcy administrators. As part of the estimated US\$10 million purchase, the Chinese group acquired both prototypes and all the program's fabrication and assembly tooling and established a new subsidiary called Fairchild Dornier Aerolndustries in Germany. According to D'Long's stated schedules, certification and the start of production would happen in 2006. D'Long itself went bankrupt in $2004 .^{43}$

\subsection{The ARJ21 project}

In 2000 COSTIND acknowledged that the aviation industry lacked the capability to produce larger planes competitively. In November 2000, COSTIND decided to commit CNY5 billion (about US\$600 million) in research and development for the ARJ21, or Asian regional jet for the 21st. AVIC I Commercial Aircraft Co. (ACAC) - an ad hoc company jointly managed by two AVIC II subsidiaries, XAC and the Shanghai Aircraft Design Institute - was created to oversee resources, production, certification and marketing. ${ }^{44}$ Development costs are relatively low, partly because ACAC has shifted some of the costs on to its suppliers, and partly because labor is cheaper than elsewhere. ${ }^{45}$ Given that aircraft, unlike cars, are still largely hand-built, salaries account for a third of an aircraft's cost and the advantage of China in this respect is an important

\footnotetext{
${ }^{43}$ See "Spreading their wings”, The Economist, 4 September 2003 and “Enigmatic D’Long in race to fund flight of relaunched 728”, Aviation International News, 25 April 2004.

${ }^{44}$ In 2000, XAC also launched the MA-60, known as the Xinzhou 60 in China. Developed from the Yun 7-200A, the MA-60 is a 56- to 60-seat turboprop with an extended fuselage, longer range and lighter airframe weight. A total of 26 MA-60s have been ordered by Chinese airlines.

45 "Senior engineers in the US earn over $\$ 100,000$ a year. That's much more than me, the vice president of the company” (in “China’s new regional aircraft a hard sell”, Asia Times, 2 September 2004).
} 
consideration. At this stage ACAC is not using composites such as Kevlar and other types of special plastics pioneered in military aircraft in the $1980 \mathrm{~s}^{46}$

The aircraft has two models - the 72-79-seat -700 and the 92-99-seat -900 . On paper at least, the ARJ21 outperforms its competitors by using shorter runways, which are not uncommon in Japan and other Asian markets, ${ }^{47}$ flying further and offering a roomier cabin and more space between seats. Moreover, CAAC specifically encouraged the use of domestically made aircraft for short regional flights. The company expects to sell about 500 ARJ21 jets in the next 20 years with 300 of them going to Chinese airlines. The goal is to control half of the regional jet market.

AVIC I subsidiaries are handling much of the manufacturing, applying the Airbus centerof-excellence model. As in the case of the MD-90, the Shanghai facility has taken responsibility for the horizontal stabilizer and final assembly. XAC would build the airplane's wings and some fuselage sections. Chengdu Aircraft, located some 400 miles southwest of Xian, would build the nose section, while Shenyang Aircraft supplies the empennage. ${ }^{48}$ Shanghai Aircraft handles final assembly. ACAC sought international cooperation in investment, design, sub-contract production, and technical consultancy. Boeing has an engineering-consulting contract to help with cockpit design and overall engineering of the new jet. This will create some common features with the 737 model, thereby improving Boeing's chances of selling more of its own airplanes in China. Foreign risk-sharing partners include General Electric for the CF34-10A engines (already used in the Bombardier and Embraer regional jets), Rockwell Collins for the ProLine 21 avionics system, Hamilton Sundstrand for the electrical system and auxiliary power unit, and Eaton for control panel. Design software comes from Dassault Systemes, the primary flight control system from Parker Hannifin, and the landing gear

\footnotetext{
${ }^{46}$ Customers still find composites difficult to repair, which is why the ARJ21 is almost entirely metal. With composites used extensively in the Airbus A380 and Boeing's 7E7, their maintenance will be firmly established and ACAC probably use them much more extensively. This gives ACAC's suppliers, especially Chengdu, which is the 7E7 composite rudder contractor, time to hone their composites craftsmanship.

${ }^{47}$ Hot weather conditions and/or high altitudes (hot and high conditions) mandate either a longer take-off run for a typical aircraft or a reduction in the usual take-off weight (less passengers and/or cargo and/or fuel) of the aircraft. I thanks Peder Andersen for help in clarifying this point.

${ }^{48}$ In late 2002 Shenyang Aircraft was selected to head R\&D of China's new stealth heavyweight fighter.
} 
from Liebherr Aerospace. Ukraine's Antonov carried out the wind tunnel testing for the supercritical wing.

According to the master schedule, by end-2004 90 per cent of the manufacturing drawings and 50 per cent of the systems drawings will be released. The ARJ21 was displayed in mockups at the February 2004 Singapore show. ACAC will use an online system similar to Boeing's to manage spare parts. ${ }^{49}$ The spare-parts and training facilities' first phase will cost CHY300/400 million (US\$36.25/48.3 million). A US\$10 million flight simulator was ordered. In November 2004 DNW, a Dutch-German wind tunnel venture which worked for Embraer, concluded high-speed testing on a 1:20-scale model, examining both Mach and Reynolds number effects. Qualitative flow visualization and sting interference evaluations also were run. Trial flights will be conducted by 2005, assembly should beginning late 2005 or early 2006, and first delivery is expected by early 2007.

So far ACAC has notched up 41 orders for the ARJ21-700, selling 20 to Shenzhen Finance Leasing and the rest to Shanghai, Shandong and other Chinese airlines at a current domestic list price of US\$25.5 million each. ${ }^{50}$ Manufacturers usually offer fat discounts on list prices. In November 2004, a deal with a local carrier for six more, possibly including the first ARJ21-900s, was expected at the fifth Airshow China in Zhuhai, one of China's five special economic zones. Sales in developed markets are on hold, however, until the aircraft passes muster with engineers and pilots responsible for shadow certification at the US Federal Aviation Administration (FAA) and the Joint Aviation Authority. Certification is unlikely in the near term, however, because there is no interest from a US airline to purchase the aircraft and the FAA will not allocate resources for this program.

\footnotetext{
49 “China’s new regional aircraft a hard sell”, cit..

${ }^{50}$ Shandong Airlines is a Bombardier customer. The two companies jointly manage a Pan Asian training centre in Qingdao. Bombardier is considering sourcing some components from three Chinese manufacturers, although it has abandoned an earlier plan to seek a joint venture to produce jets in China. The plan was discussed with a Chinese partner from 2001 to 2003. See “China’s plan could boost Bombardier”, The Globe and Mail, 28 October 2004.
} 


\subsection{Harbin Embraer Aircraft Industry (HEAl)}

Confident that its broad offering of regional jets and turboprops - from the 30-passenger EMB-120 Brasilia turboprop to the 110-passenger ERJ-195 - Embraer has been busy in Asia since the mid-1990s, considering this market the big plum for its global expansion. Since May 2000, Embraer has had a permanent office in Beijing, staffed by about 15 employees, with a Chinese-born and Brazilian-educated managing director in the person of Guan Dongyuan. Embraer clinched its first Chinese deal in 2000, when Chengdu-based Sichuan Airlines purchased five ERJ-145s and took options on more. ${ }^{51}$ The following year Southern Airlines placed 20 firm and ten option orders and Wuhan Airlines an additional ten for the ERJ-145s. However, the sale, with an approximate value of US $\$ 1$ billion, was stalled for months, as it still required final government approval. Brazilian President Fernando Henrique Cardoso personally intervened with his Chinese counterpart Jiang Zemin to speed up approval, but this did not change the situation. ${ }^{52}$ The bone of contention was the Chinese request to see Embraer produce some of the parts locally. ${ }^{53}$ In 2001 the company established a major parts presence in China, working with China Aviation Supplies Import and Export Corp. (CASC) to warehouse about US $\$ 20$ million worth of inventory.

At the 2002 Asian Aerospace in Singapore, Embraer made it clear that its goal was to make its presence in China effective and permanent by establishing a final assembly line for its regional jets. On the Chinese side there was a clear desire to develop its industry and, Brazil also being a Third World country, authorities thought that more than an assembly license could be expected from Embraer. The precedent had been set by Sino-Brazilian collaboration in satellite and space research, which culminated in a second successful launch in October 2003. In September the State Council gave its approval for outline plans to assemble the ERJ-145 in China (Figure 1). Later in the year Embraer signed a US\$50 million agreement with two companies controlled by

\footnotetext{
${ }^{51}$ Sichuan Airlines is now partially controlled by China Southern Airlines, the country's largest, through a shareholding arrangement.

52 “Embraer Sells 40 Jets To China In \$1 Billion Order”, Aviation Daily, 18 April 2001.

53 “Negócio da Embraer na China não decola”, Folha de S. Paulo, 4 April 2002.
} 
AVIC II - HAIG and its subsidiary Hafei Aviation Industry Company (HAIC).${ }^{54}$ Claiming that it needed a majority equity stake to effectively transfer technology and managerial know-how, Embraer secured a special authorization from government to keep a 51 per cent share in the joint venture and appoint four directors on the seven-strong board.

The new company, Harbin Embraer Aircraft Industry (HEAI) Company Limited, is based in Harbin, capital of the north-east province of Heilongjiang, located 900 kilometers north of Beijing. The plant would manufacture some components as well as assemble and test the planes, to be marketed primarily in China. The joint venture has a production capacity of 24 aircraft, worth about US\$19.5 million each, per year and is planned to roll out between 250 and 300 aircraft over the next ten years. The facility has a $24,000 \mathrm{~m}^{2}$ surface and staff would rise to 180 by the end of 2004 .

The aircraft maiden flight was in December 2003, a few months behind schedule. This was the first Embraer aircraft manufactured outside Brazil. In February 2004, Guangzhou's China Southern Airlines ordered six ERJ-145s, thus becoming the second local carrier to operate the aircraft. ${ }^{55}$ China Southern will deploy them on routes in the less-developed mountainous western region of the country. Embraer China sees the China Southern order as significant because it has raised hopes of other Chinese airlines ordering the aircraft for their hub-and-spoke routes. ${ }^{56}$ On 28 June 2004, the customer took delivery of the first HEAI-made aircraft, with deliveries completed in February 2005. Embraer debuted the ERJ-170 to local airlines at the second biannual Brazil-China Expo held in Shanghai in May 2004.

It is important to bear in mind that skepticism has abounded from the beginning. In 2002 Pierre Lau, a Nomura Securities analyst, argued that "high fixed costs and a comparatively late start [are] likely to work against Embraer's joint venture. Unless they

\footnotetext{
${ }^{54}$ In September of 2003, HAIC signed a cooperation contract with Bell Helicopter Textron Canada Limited and thus become the sole supplier of M430 helicopter body for Bell (Canada).

${ }_{55}$ Also in 2004, Shandong Airlines took delivery of two Bombardier CRJ700 - the first 70-seat regional jet to become operational in China or, indeed, anywhere in the Asia-Pacific region.

56 “China Southern Orders Six Embraer 145 RJs”, Aviation Daily, 1 March 2004.
} 
receive at least 20 orders a year, it would be difficult for them to be financially viable". ${ }^{57}$ As mentioned above, the company expects the plant to deliver six planes in 2004, or about half the number it had anticipated. "The speed in which the facts are happening is not the speed that we expected in the very beginning," said Botelho, who estimates the plant will make 10 aircraft in $2005 .^{58}$

The most accurate reading of the underperformance over the first two years seems to be that Embraer's expectations in terms of a more fluid access to the domestic market have not been fulfilled. Although local production avoids import duties of 24 per cent, these are being cut by WTO agreements come 2006, so the tariff-jumping argument per $s e$ is not convincing. As reported above, in the past Embraer had signed several preliminary agreements to sell planes in China, only to fail to convince their customers to sign final accords. The Brazilians thought that the willingness to engage in a not unsubstantial and long-term commitment would give it the edge over competitors like Bombardier that are still considering whether building a plant in China as well. ${ }^{59}$ Management also thought that majority ownership of HAIC would prevent the emergence of the programs that had plagued previous joint ventures. ${ }^{60}$ Nonetheless due to the still infant stage of market institutions and capitalist culture, no less than the interest on the part of buyers in extracting as many concessions as possible - doing business in China requires more patience and guanxi (relationship) than in other parts of the world. If Brazilians, coming out of a relationship culture and with less than a Northern European/American sense of time, were surprised by this and ran aground on that particular rock, the Embraer experience seems to fit the general experience of so many firms that thought they had a line on China.

Down on the shop floor finding a suitable collaborator, politically and technically, in the right place needs careful homework. Commenting on the rival Chinese and Russianbuilt regional jets, Botelho said that while there can be no doubt over their technological

\footnotetext{
${ }^{57}$ Reuters

58 “Embraer Sees Rising Jet Sales to China as Costs Fall”, Bloomberg, 30 July 2004.

59 “Optimism despite airlines’ risk aversion”, Financial Times - Special Report Aerospace, 19 July 2004.

60 "Nas asas da Embraer”, O Estado de S. Paulo, 25 June 2004.
} 
competence, these ventures may have problems in building up a serial production operation. ${ }^{61}$ On the other hand, AVIC wants larger subcontracting packages to be performed in China - the first couple of aircraft were kits flown in from Brazil and little more than the final stuffing and painting was done in Harbin.

Embraer is currently evaluating possibilities for sourcing certain parts from HAIC, in substitution of some imports. Fuselage panels would be the natural next step, but two major pre-conditions must be in place. Embraer wants more sales before contracting that work to Harbin, and the machine tools to do that must be procured first. Location and infrastructure are other important considerations, especially in light of the summer 2004 power shortage.

\section{Conclusions}

Which motivations underlie industrial reform and policies in China's aircraft industry? What role do the conversion of the military-industrial complex, privatization and foreign investment play in this strategy? Why were two competing projects launched? Why did the Chinese authorities decide to partner with Embraer, a relatively new kid in the field of global aerospace, and not with other manufacturers with a more established track record? And how real is the risk that the Chinese may be opportunistic in their acting, to protect the interests of its national champions and maximize their chances of becoming a serious global contender to Embraer?

In the first half of the 1990s the potential of the Chinese industry to mount a competitive challenge to Western aircraft builders was largely discounted (GAO 1994). Nowadays, as China strives to bear the ARJ-21 project to execution and even considers entering the market for wide-bodies, ${ }^{62}$ the threat is taken more seriously. The growth in the Chinese air transport market has reinforced the bargaining power of national aircraft producers in signing informal offset programs with Western majors and authorities are giving priority to building the science and technology capacity in this area. The seeds of

\footnotetext{
${ }^{61}$ See “Embraer hints at Russian ERJ-145 production”, Flight Daily News, 17 June 2003.

62 “China-made large planes may take off by 2018”, China Daily, 18 March 2004.
} 
"techno-nationalism" - i.e., the desire to demonstrate or acquire the status of being a technologically advanced country - are seemingly planted.

Nonetheless, industrial policy has far from proven its effectiveness. Progress in creating military/civilian synergies has proven modest - especially when compared to the shipbuilding industry. Government involvement in air transport remains significant despite the gradual shift to a more hands-off approach. Airlines still need approval from the state council and from China Aircraft Supply Corp., a government-owned company that decides on the country's aircraft purchases, to place orders. ${ }^{63}$ Decisions on where to buy planes are also intertwined with policy-makers' concerns that China's trade surpluses with the United States and, increasingly, Europe give rise to protectionism. Other policies, however, act at cross-purpose with the goal of developing manufacturing excellence in regional jets. China still charges flat landing and cabin cleaning charges for all planes and China's Air Traffic Management Bureau lets big planes fly at the level where fuel can be used economically, while the feeder planes are often guided to lower levels where more fuel is consumed. ${ }^{64}$ The prospects of setting landing fees and taxes according to the size of aircraft, which would reduce the cost of operating regional jets, remain uncertain. Nonetheless, airport construction fees for regional aircraft have already been cut to CNY 10 (US\$1.20) from CNHY 50 (US\$ 6) per passenger. ${ }^{65}$

Possibly the most fundamental issue concerns the decision to launch two competing projects. China's aircraft industry policy combines judicious opening to foreign investors and support for local firms. This may make sense insofar as it allows Chinese firms to build different skills, but the risk is that none of them reaches the level of excellence which is required to become a global competitor. The regional policy dimension, which is so compelling in the case of $\mathrm{HAEl}$, adds an additional burden. As other authors have observed, China will have difficulty following the "Asian model" of state-guided industrial

\footnotetext{
${ }^{63}$ At the end of 2004, Boeing shares fell 2.2 per cent on the announcement by CAAC of a freezing of new commercial aircraft purchases in 2005, in an effort to curb "over-heated" growth in the sector and uncontrolled capacity expansion by domestic airlines. "China to freeze aircraft orders in 2005”, Reuters, 29 December 2004.

64 “Good times ahead”, Orient Aviation, September 2004.

65 “First China-built regional aircraft takes to skies”, China Daily, 17 December 2003.
} 
growth, given its heavy and particularistic concern for firms in trouble - a tendency to support losers rather than winners (Moore 2002; Steinfeld 2004). ${ }^{66}$ Stovepiping and bureaucratic rivalries in the state-owned industry makes getting from the researchers and the R\&D facilities to design and subsequent production particularly problematic. As per the contribution of foreign investment, two years is obviously too short a period to assess an investment as complex as the one that Embraer has embarked in China. Without any guarantees for minimum orders, Embraer was confident that, with the right business sense, a product with the appropriate characteristics would easily find a place in the market. Nonetheless, the number of deals so far has failed to live up to the Brazilians' expectations, There is a suspicion that China is leveraging big buying and gate-keeping its economy to promote AVIC. AIG and GE, which want to expand their financial services business ever deeper into China, run huge aircraft leasing subsidiaries, ILFC and GECAS. Government may quietly pressure them to acquire ARJ21s in exchange to opening market gates to the mother firms.

This being said, HEAl's prospects are necessarily intertwined with those of Chinese aerospace more generally. In the market for regional jets, the current competitive position of Embraer is stronger position than McDonnell's one when it cooperated with the Chinese. ${ }^{67}$ At the same time, it is difficult to foresee the Sino-Brazilian joint venture to succeed if other, state-owned firms fail in their current plans and authorities may be tempted to push the ARJ21 project ahead of HAEI.

There is no doubt that the emergence of China's aircraft manufacturing would dramatically reshape global aerospace. However, it will take clear strategic thinking, determination, commitment and lots of money before the aerospace industry may eventually achieve credibility for more and more aircraft parts and even larger aircraft to be built in China. As this paper has shown, the industry is not immune from the various problems that plague high-end manufacturing in China - in particular, regulatory

\footnotetext{
${ }^{66}$ For a different approach, see Lau et al. (2000).

${ }^{67}$ In a promising development for Embraer, in early 2004 authorities refused Air China the authorization to use 180seat aircraft to compete with Sichuan Airlines on the Chongqing-Chengdu 300-km route. "Leis ameaçam sucesso da Embraer na China”, Folha de S. Paulo, 12 July 2004.
} 
inconsistency and opacity that push managers into pursuing short-term returns and excessive diversification rather than developing strong corporate competencies and building inter-firm relationship. 


\section{Bibliography}

Bitzinger, Richard A. (2000), "Going Places or Running in Place? China's Efforts to Leverage Advanced Technologies for Military Use", in Susan M. Puska (ed.), The PLA After Next, US Army War College, Strategic Studies Institute.

---- (2004), "Civil-Military Integration and Chinese Military Modernization", Asia-Pacific Security Studies, Vol. 3, No. 9.

---- (2005), “The PRC's Defense Industry: Reform without Improvement”, The Jamestown Foundation, China Brief, Vol. 5, No. 6.

Bureau of Export Administration (1999), U.S. Commercial Technology Transfers to the People's Republic of China, Office of Strategic Industries and Economic Security, Defense Market Research Report.

Cliff, Roger (2001), The Military Potential of China's Commercial Technology, RAND Corporation.

COSTIND (2000), The Development of China's Civil Aircraft, State Defence Industries Commission.

Doner, Richard F., Gregory W. Noble, and John Ravenhill (2004), "Production Networks in East Asia's Auto Parts Industry", in Yusuf et al..

Findlay, Christopher and Andrea Goldstein (2004), "Liberalization and Foreign Direct Investment in Asian Transport Systems: The Case of Aviation", Asian Development Review, Vol. 21, No. 1, pp. 37-65.

Frankenstein, John (1995), "The Beijing Rules: Contradictions, Ambiguities and Controls", Long Range Planning, February.

--- (1999), "China's Defense Industries: A New Course?" in James Mulvenon and Richard H. Yang (eds.), The People's Liberation Army in the Information Age, RAND Corporation,

GAO (United States General Accounting Office) (2000), World Trade Organization - Status of China's Trade Commitments to the United States and Other Members, Report to Congressional Committees, GAO/NSIAD-00-142.

---- (2004), World Trade Organization - U.S. Companies' Views on China's Implementation of Its Commitments, GAO-04-508.

Goldstein, Andrea (2002a), "From National Champion to Global Player: Explaining the Success of Embraer", CEPAL Review, No. 77.

--- (2002b), "The political economy of high-tech industries in developing countries: aerospace in Brazil, Indonesia and South Africa", Cambridge Journal of Economics, Vol. 26, No. 4, pp. 521-38.

Hartley, Keith and Derek Braddon (2001), "Aerospace competitiveness study", University of the West of England, Research Unit in Defence Economics, Monograph Series, No. 14.

Lau, Lawrence J., Ying-Yi Qian, and Gerard Roland (2000), "Reform without Losers: An Interpretation of China's Dual-Track Approach to Transition", Journal of Political Economy, Vol. 108, No. 1: 120-143.

Li, Cheng (2004), "China's Northeast: From Largest Rust Belt to Fourth Economic Engine?", China Leadership Monitor, No. 9.

Medeiros, Evan S. (2004), "Analyzing China's Defense Industries and the Implications for Chinese Military Modernization", testimony presented to the U.S.-China Economic and Security Review Commission on 6 February, The RAND Corporation, document CT-217.

Moore, Thomas G. (2002), China in the World Market: Chinese Industry and International Sources of Reform in the Post-Mao Era, New York: Cambridge University Press.

Nolan, Peter (2001), China and the Global Economy, Houndmill and New York, Palgrave.

--- (2005), "China at the crossroads", Journal of Chinese Economic and Business Studies, Vol. 3, No. 1: 1-22.

---- and Jin Zhang (2002), "The challenge of globalization for large Chinese firms", World Development, Vol. 30, No. 12, pp. 2089-2107.

---- and ---- (2003), “Globalization Challenge for Large Firms from Developing Countries:: China's Oil and Aerospace Industries", European Management Journal, Vol. 21, No. 3, pp. 285-99. 
Piore, Michael J. (2004), "The Limits of the Division of Labor in Design and the Prospects for Off-Shore Software Development in Mexico", prepared for The Software Industry in the Developing World Workshop, Yale University, 20-22 February.

Sarathy, Ravi (1985), "High-Technology Exports from Newly Industrializing Countries: The Brazilian Commuter Aircraft Industry", California Management Review, Vol. 27, No. 2.

SIPRI (2004), The Arms Transfers Project, link at www.sipri.org/contents/armstrad.

Steinfeld, Edward S. (2004), "Chinese Enterprise Development and the Challenge of Global Integration", in Yusuf et al..

Sturgeon, Timothy J. and Richard Florida (2004), "Globalization, Deverticalization and Employment in the Motor Vehicle Industry", in Martin Kenney with Richard Florida (eds.), Locating Global Advantage. Industry Dynamics in the International Economy, Stanford University Press.

Sutton, John (1998), Technology and Market Structure, Cambridge, MA: The MIT Press.

Thomke, S. and T. Fujimoto (2000), "The Effect of 'Front-Loading' Problem-Solving on Product Development Performance", Journal of Product Innovation Management, Vol. 17, No. 1.

USCC (U.S.-China Economic and Security Review Commission) (2005), U.S.-China Trade and Investment: Impact on Pacific Northwest Industries: Field Hearing in Seattle, Washington, 13 January.

US House of Representatives (1999), U.S. National Security and Military/Commercial Concerns with the People's Republic of China, Final Report of the Select Committee.

USITC (US International Trade Commission) (2001), Competitive Assessment of the U.S. Large Civil Aircraft Aerostructures Industry, Investigation No. 332-414.

Yusuf, Shahid, M. Anjum Altaf, and Kaoru Nabeshima (eds.), Global Production Networking and Technological Change in East Asia, Oxford University Press for the World Bank. 
Table 1. The Structure of AVIC 1 and 2

\begin{tabular}{|c|c|c|}
\hline & AVIC 1 & AVIC 2 \\
\hline Aircraft & $\begin{array}{l}\text { Shenyang Aircraft Corp. (AC); Chengdu Aircraft } \\
\text { Industrial Corp. (AIC); Xi'an AC; Shanxi AC; } \\
\text { Nanchang AIC }\end{array}$ & $\begin{array}{l}\text { Harbin AIC; Hongdu AIC; Harbin Aviation Industry } \\
\text { Group; Shijiazhuang AIC; Changzhou, Baoding } \\
\text { (Propeller), Xiangling (Machinery), and Hongtu } \\
\text { Factories }\end{array}$ \\
\hline Helicopters & & Jiangxi Changhe Aviation Industries Company \\
\hline Engine and Supporting & $\begin{array}{l}\text { Harbin Dongan Engine Manufacturing; Guizhou } \\
\text { Honglin Machinery; Zhongnan Transmission } \\
\text { Machinery Works; China National South Aeroengine; } \\
\text { Chengdu Engine; Xian Aeroengine; Guizhou Liyang } \\
\text { Aeroengine; Guizhou Xinyi Machinery Factory. }\end{array}$ & $\begin{array}{l}\text { China National South Aeroengine; Beijing Chang } \\
\text { Kong Machinery; Chengdu Engine; Changzhou } \\
\text { Lanxiang Machinery Works; Zhongnan } \\
\text { (Transmission Machinery) and Changjiang (Engine } \\
\text { \& Machinery) Factories }\end{array}$ \\
\hline $\begin{array}{l}\text { Airborne Equipment \& } \\
\text { Specialized } \\
\text { Manufacturers }\end{array}$ & $\begin{array}{l}\text { Qingan Group; Changchun Airborne Equipment; } \\
\text { Chengdu Aero-Instrument; Shanxi Qinling } \\
\text { Aeroelectric; Jianghan Aviation Lif-Support; China } \\
\text { Xingping Aircraft Wheel; Qingyun Aviation } \\
\text { Instrument; Jincheng Group; Chuanjiang, Pingyuan, } \\
\text { Shenyang Xinhua, Huayang, Shanghai, Yuxin, Wanli, } \\
\text { Changfeng, Wuhan, Guiyang, Luoyang Nanfeng, } \\
\text { Taihang, Beijing Jianghuai, Nanjing Hongyuang, } \\
\text { Hongwei, Sanjiang, Chuanxi Factories }\end{array}$ & $\begin{array}{l}\text { Beijing Shuguang; Xinhang; Sichuan Fanhua; } \\
\text { Chuanjiang; Sanjiang; Lanzhou; NanJin Hongguang; } \\
\text { TianJin; Wuhan; Chuanxi; Changchun; Zhengzhou } \\
\text { XinWei; Wanli; Sichuan; Xuzhou; Qingdao Qianshao; } \\
\text { Jingdezhen; Baoding Xiangyang }\end{array}$ \\
\hline Other & $\begin{array}{l}\text { China National Aero-Technology Import and Export } \\
\text { Corporation (CAITC); Changhe AIC; Shanghai AIC; } \\
\text { Guizhou AIC }\end{array}$ & $\begin{array}{l}\text { Hanzhong Aviation Industry (Group) (including } 18 \\
\text { Manufacturers) as well as } 24 \text { other enterprises \& } \\
\text { Institutes }\end{array}$ \\
\hline $\begin{array}{l}\text { Research Institutes \& } \\
\text { Schools }\end{array}$ & $\begin{array}{l}\text { Beijing University of Aeronautics and Astronautics; } \\
\text { Nanjing University of Aeronautics and Astronautics; } \\
\text { Northwest Poly-Technical University; Chinese } \\
\text { Society of Aeronautics and Astronautics; Beijing } \\
\text { Institute of Aeronautical Materials; Aircraft Strength } \\
\text { Research Institute of AVIC; Beijing Aeronautical } \\
\text { Manufacturing Technology Research Institute; China } \\
\text { Aero-Information Center; China Aeronautical } \\
\text { Project and Design Institute; } 18 \text { other institutes. }\end{array}$ & $\begin{array}{l}\text { Chinese Helicopter Research and Development } \\
\text { Institute; Zhuzhou Aviation Power Plant Research } \\
\text { Institute; Chinese Special Vehicles Research } \\
\text { Institute }\end{array}$ \\
\hline
\end{tabular}




\section{Table 2. Main Airbus and Boeing Subcontracting Work in China}

\begin{tabular}{|l|r|r|r|r|}
\hline & Shanghai & Xi'an & Chendgu & Shenyang \\
\hline Airbus $^{1}$ & & $\begin{array}{r}\text { A320 wing leading } \\
\text { edge assemblies and } \\
\text { electronics bay doors } \\
\text { (sole supplier) }\end{array}$ & $\begin{array}{r}\text { A320 forward nose } \\
\text { section parts and rear } \\
\text { passenger door (one } \\
\text { of two suppliers) }\end{array}$ & $\begin{array}{r}\text { A320 fixed leading } \\
\text { edges, wing interspar } \\
\text { ribs, and emergency } \\
\text { exit doors (sole } \\
\text { supplier) \& } \\
\text { A330/A340 forward- } \\
\text { cargo door }\end{array}$ \\
\hline Boeing & B737 even tail & $\begin{array}{r}\text { B737 vertical fins, } \\
\text { horizontal stabilizers } \\
\text { and access gates }\end{array}$ & 757 empennage & $\begin{array}{r}\text { whole tail sections } \\
\text { and cargo doors }\end{array}$ \\
\hline
\end{tabular}

(1) Hong Yuan Aviation Forging \& Casting (HYFC), based in Sanyuan county in Shaanxi Province, is producing titanium forging parts, which are used to mount aircraft powerplants to wings. Guizhou Aviation Industrial Group produces maintenance jigs and tools.

Source: companies.

\section{Table 3. Trade in Aircraft, Spacecraft, and Parts Thereof}

(US\$ billion)

\begin{tabular}{|l|r|r|r|}
\hline & Exports & Imports & \multicolumn{1}{|c|}{ Deficit } \\
\hline 1997 & 2.91 & 32.35 & 29.44 \\
\hline 1998 & 4.40 & 31.75 & 27.35 \\
\hline 1999 & 5.68 & 31.75 & 26.07 \\
\hline 2000 & 5.36 & 21.71 & 16.35 \\
\hline 2001 & n.a. & 44.31 & n.a. \\
\hline 2002 & 4.39 & 40.52 & 36.13 \\
\hline 2003 & 4.39 & 44.61 & 40.22 \\
\hline
\end{tabular}

Source: China Customs 


\section{DAVIDSON INSTITUTE WORKING PAPER SERIES - Most Recent Papers}

The entire Working Paper Series may be downloaded free of charge at: www.wdi.bus.umich.edu

CURRENT AS OF 7/6/05

\begin{tabular}{|c|c|c|}
\hline Publication & Authors & Date \\
\hline $\begin{array}{l}\text { No. 779: The Political Economy of Industrial Policy in China: The Case } \\
\text { of Aircraft Manufacturing }\end{array}$ & Andrea Goldstein & July 2005 \\
\hline $\begin{array}{l}\text { No. 778: Bank Supervision Russian style: Rules versus Enforcement } \\
\text { and Tacit Objectives }\end{array}$ & $\begin{array}{l}\text { Sophie Claeys, Gleb Lanine and } \\
\text { Koen Schoors }\end{array}$ & June 2005 \\
\hline No. 777: Labor Market Trends and Institutions in Belarus & $\begin{array}{l}\text { Zuzana Brixiova and Vera } \\
\text { Volchok }\end{array}$ & June 2005 \\
\hline $\begin{array}{l}\text { No. 776: Can Vietnam Achieve One of its Millennium Development } \\
\text { Goals? An analysis of schooling dropouts of children }\end{array}$ & $\begin{array}{l}\text { Vo Tri Thanh And Trinh Quang } \\
\text { Long }\end{array}$ & June 2005 \\
\hline $\begin{array}{l}\text { No. 775: Is The Link Between Reforms And Growth Spurious? A } \\
\text { Comment }\end{array}$ & Tomasz Mickiewicz & May 2005 \\
\hline $\begin{array}{l}\text { No. 774: The Risk Aversion of Banks in Emerging Credit markets: } \\
\text { Evidence from India }\end{array}$ & $\begin{array}{l}\text { Sumon Kumar Bhaumik and } \\
\text { Jenifer Piesse }\end{array}$ & May 2005 \\
\hline $\begin{array}{l}\text { No. 773: Organized Labor and Restructuring: Coal Mines in the Czech } \\
\text { Republic and Romania }\end{array}$ & $\begin{array}{l}\text { Jan Bruha, Delia Ionascu, and } \\
\text { Byeongju Jeong }\end{array}$ & May 2005 \\
\hline $\begin{array}{l}\text { No. 772: Is Political Risk Company-Specific? The Market Side of the } \\
\text { Yukos Affair }\end{array}$ & $\begin{array}{l}\text { Alexei Goriaev and Konstantin } \\
\text { Sonin }\end{array}$ & May 2005 \\
\hline $\begin{array}{l}\text { No. 771: Non-Linear Exchange Rate Dynamics in Target Zones: A } \\
\text { Bumpy Road Towards A Honeymoon }\end{array}$ & $\begin{array}{l}\text { Jesús Crespo-Cuaresma, Balázs } \\
\text { Égert, and Ronald MacDonald }\end{array}$ & May 2005 \\
\hline $\begin{array}{l}\text { No. 770: Equilibrium Exchange Rates in Southeastern Europe, Russia, } \\
\text { Ukraine and Turkey: Healthy or (Dutch) Diseased? }\end{array}$ & Balázs Égert & May 2005 \\
\hline $\begin{array}{l}\text { No. 769: Equilibrium Exchange Rates in Central and Eastern Europe: A } \\
\text { Meta-Regression Analysis }\end{array}$ & Balázs Égert and László Halpern & May 2005 \\
\hline $\begin{array}{l}\text { No. 768: Testing for inflation convergence between the Euro Zone } \\
\text { and its CEE partners }\end{array}$ & Imed Drine and Christophe Rault & Apr. 2005 \\
\hline $\begin{array}{l}\text { No. 767: Labor Mobility during Transition: Evidence from the Czech } \\
\text { Republic }\end{array}$ & Jan Fidrmuc & Apr. 2005 \\
\hline $\begin{array}{l}\text { No. 766: Formation of social capital in Central and Eastern Europe: } \\
\text { Understanding the gap vis-à-vis developed countries }\end{array}$ & Jan Fidrmuc and Klarita Gërxhani & Apr. 2005 \\
\hline $\begin{array}{l}\text { No. 765: Do Regional Integration Agreements Increase Business-Cycle } \\
\text { Convergence? Evidence From APEC and NAFTA }\end{array}$ & $\begin{array}{l}\text { Viviana Fernandez and Ali M. } \\
\text { Kutan }\end{array}$ & Apr. 2005 \\
\hline $\begin{array}{l}\text { No. 764: State Regulations, Job Search and Wage Bargaining: A Study } \\
\text { in the Economics of the Informal Sector }\end{array}$ & Maxim Bouev & Apr. 2005 \\
\hline $\begin{array}{l}\text { No. 763: The Feldstein-Horioka Puzzle Revisited: An “European- } \\
\text { Regional” Perspective }\end{array}$ & $\begin{array}{l}\text { Jérôme Hericourt and Mathilde } \\
\text { Maurel }\end{array}$ & Apr. 2005 \\
\hline $\begin{array}{l}\text { No. 762: Transatlantic Differences in Labour Markets Changes in Wage } \\
\text { and Non-Employment Structures in the 1980s and the 1990s }\end{array}$ & Patrick A. Puhani & Mar. 2005 \\
\hline $\begin{array}{l}\text { No. 761: Resolution, Recovery and Survival: The Evolution of Payment } \\
\text { Disputes in Post-Socialist Europe }\end{array}$ & William Pyle & Mar. 2005 \\
\hline $\begin{array}{l}\text { No. 760: Official Foreign Exchange Interventions in the Czech } \\
\text { Republic: Did They Matter? }\end{array}$ & Balázs Égert and Luboš Komárek & Mar. 2005 \\
\hline $\begin{array}{l}\text { No. 759: Assessing Market Expectations on Exchange Rates and } \\
\text { Inflation: A Pilot Forecasting System for Bulgaria }\end{array}$ & $\begin{array}{l}\text { Michael Berlemann, Kalina } \\
\text { Dimitrova, \& Nikolay Nenovsky }\end{array}$ & Mar. 2005 \\
\hline No. 758: Attitudes and Performance: An Analysis of Russian Workers & $\begin{array}{l}\text { Susan J. Linz and Anastasia } \\
\text { Semykina }\end{array}$ & Mar. 2005 \\
\hline $\begin{array}{l}\text { No. 757: Barter, Credit, and Welfare: A theoretical inquiry into the } \\
\text { barter phenomenon in Russia }\end{array}$ & José Noguera and Susan J. Linz & Mar. 2005 \\
\hline $\begin{array}{l}\text { No. 756: Sorting, Selection, and Transformation of the Return to } \\
\text { College Education In China }\end{array}$ & $\begin{array}{l}\text { Belton M. Fleisher, Haizheng Li, } \\
\text { Shi Li, and Xiaojun Wang }\end{array}$ & Mar. 2005 \\
\hline $\begin{array}{l}\text { No. 755: Foreign Exchange Interventions in Emerging Europe: } \\
\text { Should We Give a Damn? The Case of Croatia and Turkey }\end{array}$ & Balázs Égert and Maroje Lang & Mar. 2005 \\
\hline $\begin{array}{l}\text { No. 754: Targeting Relative Inflation Forecast as Monetary Policy } \\
\text { Framework for Adopting Euro }\end{array}$ & Lucjan T. Orlowski & Feb. 2005 \\
\hline $\begin{array}{l}\text { No. 753: Internet Entrepreneurship: Networks and Performance of } \\
\text { Internet Ventures In China }\end{array}$ & Bat Batjargal & Feb. 2005 \\
\hline
\end{tabular}

